\title{
Restorative Justice for Trayvon Martin
}

\author{
Mikhail Lyubansky \\ University of Illinois, Urbana-Champaign
}

\begin{abstract}
Two cities. Two people of color fatally shot by those charged with security and law enforcement. Two communities torn apart across racial lines. One city reacts conventionally with criminal charges and court proceedings. The other similarly engages the legal system but additionally engages in a Restorative Circle, a restorative process designed to create conditions for mutual understanding and repair of harm. In this article, the case of Trayvon Martin is juxtaposed with a less well-known case in Seattle involving the death of Native American woodcarver, John T. Williams. The two cases are summarized and examined in terms of their racial dynamics and the subsequent differential impact of the restorative response on the Seattle community.
\end{abstract}

Keywords. Trayvon Martin, restorative justice, criminal justice, racism

Fifty-seven years ago, in 1955, fourteen-year-old Emmett Till was slain while visiting his relatives in Mississippi. Till's murder (and the consequent acquittal of Roy Bryant and his halfbrother J. W. Milam) sparked outrage throughout the Black $^{1}$ community and is widely considered to have been a catalyst for the Civil Rights movement.

This past February (Feb 26, 2012), seventeen-year-old Trayvon Martin was slain while visiting his relatives in Florida. Like Till's, Martin's death has outraged the Black community and its allies and exacerbated an already tense racial climate across the nation. It remains to be seen whether it similarly mobilizes social reform, but the mere possibility of such mobilization underscores the importance of this story and makes the similarities to Till impossible to ignore.

I do not want to exaggerate the similarities. There is a general consensus that Till's murder was pre-meditated and racially motivated for the purpose of keeping "Negroes" in their place (Till

\footnotetext{
1 The racial identifiers "Black" and "White" are used throughout the article to refer to socially constructed groups. The use of these terms reflects popular usage and is not intended to lend scientific support for these constructed categories, which are politically and ethnically heterogeneous.
} 
had reportedly flirted with a White woman, the wife of Roy Bryant). Despite his and Bryant's acquittal, Milam admitted to the murder in a 1956 interview with Look magazine, and in posttrial interviews, the jurors acknowledged that they knew Bryant and Milam were guilty but were unwilling to convict because they did not believe life imprisonment or the death penalty was an appropriate punishment for a White person who had killed a Black man (Beito \& Beito, 2009).

At the time of this writing, the circumstances leading up to Martin's death are still in dispute, and I make no claim here to know what happened that day. Those facts are important, as Martin's life and every other individual life is important, but like the Till case, Martin's story is larger than what happened during the moments leading up to his death. Like Till's story, Martin's is also about the racial context of our time and similarly has implications for how we might best move toward a racially just society.

Whatever the facts and circumstances of Martin's death turn out to be, there are two things that must be considered if one wants to understand what happened and think about how to move forward. One is sociological; the other psychological. I will elaborate on both but first some relevant data regarding Americans' perceptions concerning what happened.

\section{The Racial Divide}

George Zimmerman claims that his initial suspicion of Martin was not racially motivated. Whether or not you believe him is largely determined by how you identify racially. For example, a Christian Science Monitor/TIPP poll of 906 adults taken from March 30 to April 5 found that twice as many Blacks and Hispanics (73\%) as Whites (36\%) say race played a major role in Martin's death. Similarly, an April 2-4 USA Today/Gallup poll of 3,006 Americans found that Blacks were more than twice as likely as non-Blacks (73\% to 33\%) to believe that Zimmerman (who is White and Hispanic) is guilty of a crime in shooting Martin (Alcindor, 2012).

As startling as the above racial divide may appear, it is actually quite consistent with other data, which show that Blacks and Whites have vastly different perceptions regarding the realities of racial inequality. For example, according to national surveys conducted by the National Opinion Research Center (NORC), $66 \%$ of Blacks but only $34 \%$ of Whites thought that racial inequality in jobs, income, and housing was primarily the result of discrimination (Schuman, Steeh, Bobo, \& Krysan, 1997).

Broadcaster Geraldo Rivera seemed to capture the spirit of the nation, when, in reference to Martin's death, he observed "Half the nation, generally younger and more minority, believes a grave injustice has been done. The other half, generally older and whiter, believes that a mob led by professional agitators is trying to railroad Zimmerman for their own political purposes" (Knickerbocker, 2012).

Without doubt, the different life experiences of the two sides of the color line contribute heavily to this discrepancy. However, as I and others have observed elsewhere (e.g., Eidelson \& Lyubansky, 2010; Omi \& Wynant, 1994) it also seems relevant that Whites tend to locate racism in racial-consciousness (and therefore see "color-blindness" as the solution), while Blacks are more likely to (1) see racism as a system of power and privilege and (2) regard the 
affirmation of difference and racial identity as a core element of their historical and present experience.

In this context, President Obama's comments about the Martin case take on even more significance. Obama campaigned and got elected using a post-racial discourse and has consistently minimized the impact of race since the 2004 Democratic National Convention, when, to great applause, he proclaimed, "There's not a Black America and White America and Latino America and Asian America; there's the United States of America." (Washington Post, 2004). With the 2012 election on the horizon and his political future depending in no small part on his ability to again persuade voters to see beyond race, the President nevertheless publicly opined that the shooting may have been racially motivated. "If I had a son," Obama observed, "he would look like Trayvon" (Condon, 2012).

Is it possible, then, that we do, in fact, live in a Black America and a White America, with race playing a key role in practically every outcome that matters, as well as in the perception of how those outcomes are shaped and determined? A thorough review of racial inequities and their causes is beyond the scope of this paper, but our increasing understanding of racial profiling is instructive and provides some of the necessary sociological context for understanding the events that led to Martin's death.

\section{The Sociological Backdrop}

Consider some recent racial profiling data from my home state of Illinois, where the Illinois Department of Transportation (IDOT) has been compiling racial profiling data for almost 10 years. According to the 2010 data (the most recent available at the time of this writing), "minority drivers" were $12 \%$ more likely to be stopped, after controlling for demographic differences in population (IDOT, 2010). Nationally, the numbers may be much higher, as data from a national sample of 7,034 people stopped by police in previous 12 months indicate that Black men are $35 \%$ more likely than White men to report being stopped by police for a traffic violation ${ }^{2}$ (Lundman \& Kaufman, 2003).

What follows the stops also reveals racial bias. For example, data from New York City's Police Department shows that Blacks were 12 times more likely than Whites to be stopped with physical force and 40 times more likely to be stopped by having a gun drawn on them by a police officer (Ogletree, 2010). The state of Illinois does not track the use of physical force, but according to the IDOT 2010 report, Black drivers in Illinois were almost twice as likely to have the police request to search their car (1.64\% of traffic stops), compared to White drivers ( $0.88 \%$ of traffic stops). Similarly, in their analysis of outcomes of pedestrian and motor vehicle stops by the Los Angeles Police Department from July, 2003 to June, 2004, Ayres and Borowsky (2008) conclude that the data show "prima facie evidence that African Americans and Hispanics are over-stopped, over-frisked, over-searched, and over-arrested." More specifically, the report states that when stopped by police, Black drivers and pedestrians are $127 \%$ more likely to be frisked, $76 \%$ more likely to have their vehicle searched, and $29 \%$ more likely to be arrested relative to their White counterparts. The discrepancy is smaller but still significant for

\footnotetext{
${ }^{2}$ Notably, there were no race group differences for women.
} 
Hispanics who were $43 \%$ more likely to be frisked, $16 \%$ more likely to be searched, and $32 \%$ more likely to be arrested ${ }^{3}$.

When confronted with such data, police officers (and department representatives) usually respond that they are just doing their job -- that the racial discrepancy in stops and searches merely reflects group differences in unlawful behavior. Yet, the data clearly suggest otherwise. In 2010, the previously mentioned police search requests in Illinois yielded contraband (weapons, drugs, or unlawfully acquired money) for $19 \%$ of Black drivers compared to $25 \%$ of Caucasian drivers (IDOT, 2010). The exact same pattern is evident in Los Angeles, where the frisks and searches are systematically less productive when conducted on Blacks and Hispanics than when conducted on Whites. More specifically, Ayres and Borowsky (2008) report the following:

- Frisked African Americans are $42.3 \%$ less likely to be found with a weapon than frisked Whites and that frisked Hispanics are $31.8 \%$ less likely to have a weapon than frisked non-Hispanic Whites.

- Consensual searches of Blacks are $37.0 \%$ less likely to uncover weapons, $23.7 \%$ less likely to uncover drugs and $25.4 \%$ less likely to uncover anything else.

- Consensual searches of Hispanics similarly are $32.8 \%$ less likely to uncover weapons, $34.3 \%$ less likely to uncover drugs and $12.3 \%$ less likely to uncover anything else.

These numbers are not an aberration. Though the L.A. data were only reported for a single year, the 2010 Illinois data are very near the state's 6-year average (i.e., contraband found in $15 \%$ of searches of Black drivers, compared to $24 \%$ for White drivers). If the vehicle search requests were motivated solely by probable cause and racial profiling was nonexistent, the rates of contraband should not differ across racial groups.

Are police officers racist? What about Zimmerman, who was not a police officer at the time of the incident with Martin but was functioning in a somewhat similar capacity in his position as the community watch coordinator? Does this type of work bring out racist tendencies or is it that those who have such tendencies to begin with are more likely to self-select into law enforcement? There is no way to be certain about the motivations of specific individuals, but the psychological literature does provide a fascinating possible explanation for both the racial profiling inequities and the actions of law enforcement officers as a group.

\section{Unconscious Bias}

I have no way of knowing whether Zimmerman was lying or telling the truth when he claimed his actions were not racially motivated. In the unlikely scenario that this case goes to trial, considerable time and energy will be expended in an attempt to determine what he was thinking when he first dialed the police non-emergency number to report a suspicious person

\footnotetext{
${ }^{3}$ These numbers may well be influenced by regional politics, as for example, in Arizona, which in 2010 enacted SB 1070 , a law requiring police officers to verify the citizenship of individuals they stop if they have reasonable suspicion that they may be in the United States without unlawfully. The majority of SB 1070 was struck down by the U.S. Supreme Court in 2012.
} 
and, again, when he decided to pursue Martin against the police dispatcher's recommendation. On the one hand, this is an important question, as it can help establish intent. On the other, it doesn't much matter as hundreds of studies consistently show that most people's actions are affected by bias they are not even aware they have. This is evident in a variety of different domains. For example, according to the Institute of Medicine (2002) report on racial and ethnic disparities in health care, when Latinos and African Americans are treated by physicians for a broken bone in their leg, they receive pain medication significantly less often than White patients with the same injury. According to the same report:

... minorities are less likely to be given appropriate cardiac medications or to undergo bypass surgery, and are less likely to receive kidney dialysis or transplants. By contrast, they are more likely to receive certain less-desirable procedures, such as lower limb amputations for diabetes and other conditions.

These findings, which control for insurance status, income, age, and severity of conditions, are likely to be met with disbelief by the well-trained medical professionals who work hard to give all their patients the best care possible. Indeed, there is no evidence that the discriminatory treatment is intentional. To the contrary, studies like this help us understand that when people hold a negative stereotype about a group, they often treat members of that group differently without even realizing it. We may not like to know this about ourselves, but it seems to be a human characteristic, at least in contemporary society where racial socialization is so strong and negative racial stereotypes so common.

Of course, doctors are not the only ones who express unconscious racial bias. Phillip Goff (Godsil, Goff, powell ${ }^{4}$, Williams, \& Hinojosa, 2012) found that law enforcement officials are influenced by unconscious bias not only when it comes to race, but also in regard to what they perceive to be threats to their masculinity. According to Goff (Godsil et al., 2012), over 80\% of incidents that involved police use of deadly force were preceded by threat to the officers' masculinity (e.g., being called a "fag"). In fact, Goff's research suggests that threats to masculinity were much more predictive of White officers' deadly use of force against Blacks (in highly realistic simulation exercises) than explicit measures of racial prejudice (Godsil et al., 2012). It turns out that racism (i.e., acts that have racist outcomes), is not necessarily perpetrated by racists ${ }^{5}$ but by people who feel threatened (or stressed out) for other reasons and are not aware of their racial bias.

Studies of unconscious bias (also known as implicit bias) go back to at least 1998, when psychologists at Harvard introduced the Implicit Association Test (IAT, Greenwald, McGee, \& Schwartz, 1998). Since that time, they've gained recognition and prominence among both academics and racial justice activists ${ }^{6}$, but, for the most part, this research is still unknown and still largely absent from most policy deliberations.

Goff's findings may allow us to reconcile the existence of racial inequity in a variety of different domains with the increasingly popular rhetoric (especially among White conservatives) that

\footnotetext{
${ }^{4}$ john powell's name is intentionally not capitalized according to his preference.

${ }^{5}$ In this paper, the term "racist" is used to refer to those who either self-identify in this way or who otherwise explicitly self-report racial prejudice.

${ }^{6}$ As just one example, studies of implicit bias were prominently featured at the W.K. Kellogg Foundation's 2012

America Healing conference designed to move our society from a "racialized democracy" to an inclusive one.
} 
racism no longer exists (Brown et al., 2003). They also allow us to understand how Blacks and Whites can have such different perceptions (described previously) of the same reality, including the altercation between Zimmerman and Martin.

Neither the data nor the conclusions should be viewed fatalistically. To the contrary, they provide not only hope that change is possible but a specific strategy for working toward such change. In the America Healing plenary session he shared with Goff and others, john powell, the Director of the Haas Center for Diversity and Inclusion and Robert D. Haas Chancellor's Chair in Equity and Inclusion at the University of California Berkeley, elaborated. "The fact that we have these deep, unconscious biases - and it's conflicted around race ... doesn't make us racist. It makes us human. And if we're going to address it, we have to acknowledge that." (Godsil et al., 2012).

Martin's death is a painful reminder of this crucial point: Unless we intentionally go out of our way to learn about and become aware of our own bias, it is likely to spill out at the most inopportune time, like during a stressful traffic stop (in the case of a law enforcement officer) or during a medical emergency in the ER. The good news is that it doesn't have to. Rather, we have to learn to become aware of and be willing to acknowledge our own biases and then consciously override them. This is no easy task - to the contrary, psychologist Susan Fiske calls it a "hard choice" (Fiske, 1989) - but it is a choice, a choice that all of us are capable of making once we realize that professed racial color-blindness is not only not useful but can be downright dangerous.

Unfortunately, this is not just a policing (or community watch) issue. Similar bias is evident in the U.S. incarceration rates, where the racial disparities are so high that, in the words of attorney and writer Michelle Alexander, "the racial dimension of incarceration is its most striking feature." (Alexander, 2010, p.6). Alexander's book is filled with data that support this assertion. In Washington, D.C., for example, "it is estimated that three out of four young Black men (and nearly all those in the poorest neighborhoods) can expect to serve time in prison" (Braman, 2004, citing D.C. Department of Corrections data from 2000).

Obama's words at the 2004 Democratic convention aside, we do seem to live in a Black America and a White America, at least when it comes to issues of crime and justice, and most Black Americans (as well as many White Americans) know it. The literature on unconscious bias provide us with one strategy for moving forward - a personal exploration of our own hidden biases - but a systemic issue also requires a systemic response.

\section{A Restorative Response}

What is it that we really want when we say we want justice? Several years ago I would have easily answered "true equality under the law" -- as opposed to our current criminal justice system, in which race clearly plays a major role. More to the point, I would have said that I wanted the determination of guilt and the administration of punishment to not be correlated to race or any other demographic characteristic. In the context of Trayvon Martin's death, this would mean that neither Martin's blackness nor Zimmerman's mixed ethnicity should play a role in the determination of Zimmerman's guilt and, if necessary, his punishment (i.e., sentence). 
Today, the absence of racial bias continues to be important to me, but I no longer consider it sufficient, not in general and especially not in regard to Martin's death. In Zen and the Art of Motorcycle Maintenance, author Robert Pirsig writes

People arrive at a factory and perform a totally meaningless task from eight to five without question because the structure demands that it be that way. There's no villain, no 'mean guy' who wants them to live meaningless lives, it's just that the structure, the system demands it and no one is willing to take on the formidable task of changing the structure just because it is meaningless. But to tear down a factory or to revolt against a government or to avoid repair of a motorcycle because it is a system is to attack effects rather than causes; and as long as the attack is upon effects only, no change is possible. The true system, the real system, is our present construction of systematic thought itself, rationality itself, and if a factory is torn down but the rationality which produced it is left standing, then that rationality will simply produce another factory. If a revolution destroys a systematic government, but the systematic patterns of thought that produced that government are left intact, then those patterns will repeat themselves in the succeeding government. There's so much talk about the system. And so little understanding. (Pirsig, 1974, pg. 98)

There is little doubt the current criminal justice system is broken but reforming this system would be, as Pirsig so aptly describes, to attack the effects rather than causes. What we need is not a reformation of the current system but an entire new paradigm for "doing justice."

For those of us living in the United States, "doing justice" is mostly synonymous with administering punishment. We may not literally follow the Biblical edict of "an eye for an eye", but justice in American society (and in Western society more broadly) is generally based on the notion that "the punishment must fit the crime". Indeed, the punitive/retributive paradigm is so dominant that, in my experience, most Americans, even those who have reason to distrust our contemporary approach to justice, have a hard time imagining doing justice any other way. There is, however, another paradigm, a restorative one.

There are many different restorative practices - some with ancient roots, some quite new - but they all generally seek to make possible a more sustainable response to crime and other types of painful conflict by bringing together the relevant parties and creating a space where their voices may be heard. Unlike mediation, which is primarily an individual-level response, Restorative Justice is an international social movement focused on researching and implementing formal (i.e., in courts and prisons), semi-formal (i.e., in schools and churches), and informal (i.e., in families and community groups) justice systems to support individuals and communities in having conflicts, including racial conflicts, by creating conditions for mutual understanding and collaborative action, rather than seeking to exclude or punish any of the parties to the conflict.

For several years now I have been intrigued by the potential of one particular restorative practice, Restorative Circles (RC), a system originally developed by Dominic Barter and his associates in the shanty towns of urban Brazil and that is now spreading across the world. Unlike the conventional justice system, which focuses exclusively on the person identified as having broken a law, the RC process seeks to create a system which values and attempts to address the needs of all those who were either directly involved or impacted by what happened. 
In the case of Trayvon Martin, the RC process would bring together not only Zimmerman and Martin's family but likely a large group of community members who also feel impacted. A recent fatal shooting in Seattle involving the police provides a window into how RC can provide a way for communities to handle conflicts, including racial conflicts, compassionately rather than punitively, as well as to heal and learn from these conflicts. Andrea Brenneke, the attorney originally hired to represent the victim's family, described the original incident, the audio of which was captured by squad car's camera’:

On August 30, 2010, a Seattle police officer shot and killed John T. Williams, a First Nations wood carver, while he was walking down a sunny downtown street with the tools of his trade - a piece of wood and a small carving knife. The officer got out of his car, walked toward Mr. Williams with a drawn gun, and yelled three times to "Put the knife down!" Seconds later, he fired four times, killing him. The officer later testified he felt threatened by the knife. (Brenneke, 2012)

While the Williams case did not garner the kind of national media attention that the Martin case has, it was widely covered by the Seattle media and the resulting local racial tension and division was quite pronounced. The weeks that followed the shooting saw emotionally charged protests and demonstrations and community meetings filled with expressions of grief and anger. In part because the Williams shooting was just the latest in a series of interactions in which Seattle police officers used deadly force against members of minority communities, the incident sparked widespread outrage, revealed cultural misunderstanding, and exposed a lack of trust between the police department, and both the Native American community (and its allies) and other economically marginalized communities. For many civilians, the Williams shooting was part of a pattern that increased a sense of vulnerability and lack of safety with the police. On the other side of the divide, many police officers were themselves on edge, anxious about their own vulnerability and safety after two Seattle police officers were shot and killed while parked in their marked car, targeted simply because they were police (Brenneke, 2012).

In this tense climate, the Seattle Police Department convened its firearms review board, the machinery of the criminal justice system was activated, and the MacDonal Hoague \& Bayless law office undertook representation of the Williams family civil rights claims. Meanwhile, tensions between the family and police and between the Native community and police were building, and there seemed no clear strategy for addressing the immediate needs for safety and trust between the family, the community, and the police department, much less the racial undertones that are always present when White police officers shoot a person of color (Brenneke, 2012).

The case seemed destined for years of the usual antagonistic and divisive criminal and civil proceedings $s^{8}$ when Andrea Brenneke, the attorney who was to represent the family in a civil suit, proposed something radically different, a Restorative Circle involving Williams's family, the police department, and members of the community impacted by what happened. After presenting this option and getting permission to proceed from Williams' family, Brenneke

\footnotetext{
${ }^{7}$ See http://www.youtube.com/watch?v=vcxqyp2wOzE

${ }^{8}$ The O.J. Simpson proceedings are the most recognized example of how the criminal and civil processes typically unfold in these kinds of public cases. The Martin/Zimmerman case is now unfolding similarly, with multiple hearings, judge changes, and other legal maneuverings over the period of many months.
} 
approached the police department. As she later wrote, "Faced with community outrage over a problematic shooting that would require a lengthy investigation process, Chief Diaz embraced the invitation and a cutting-edge approach that would provide him and the Seattle Police Department an immediate opportunity to address the pain and issues involving the family and the larger community" (Brenneke, 2012, Community Anger, Tensions, and Wisdom section).

Though in this particular case, Chief Diaz and other members of the Seattle Police Department chose to participate in the restorative process, open-hearted participation by police (or any other party) is not essential to such a process taking place. Sometimes, those who wear the hat of legitimate authority (e.g., law enforcement officers, judges, parents, teachers) choose not to participate because they are reluctant to let go of the need for control. Other times, it is those who were harmed who refuse to participate, because doing so does not feel safe or because they are only able to focus on punitive outcomes. In still other times, as in this case, it is those who did the harm that choose not to participate. In all three circumstances, initial refusal sometimes turns into willingness ${ }^{9}$, but even if does not, the process moves forward, as it did in this case, as long as there are those who want to engage in this manner.

To those unfamiliar with restorative practices, a process such as RC may appear idealistic, naïve, and irresponsible. After all, it intentionally rejects the two core aspects of conventional approaches: the assignment of blame and the administration of punishment. As Lyubansky and Barter (2011, p. 39) point out, "We have become so accustomed to punishment as synonymous with justice that sometimes it is only through a direct, non-satisfactory experience with the retributive justice system, or direct, positive experience of a restorative process, that we come to see how limited a substitute the retributive system is for what those that experience themselves as victims say they seek: demonstration of self-responsibility, regret, and healing action by those whose acts they associate with their pain."

At the heart of the RC process is a dialog model, but it is a decidedly different type of dialog than people usually engage in, and it's not just dialog. The RC process is designed to lead to voluntary acts offered to repair or restore the relationship. The words repair and restore are not synonymous. Reparative acts have to do with compensation -- paying for a broken window is a reparative act -- while restorative acts are those whose value is largely symbolic, a heart-felt apology may qualify, or a basket of vegetables from one's garden, or an invitation to dinner, or a job offer. It is certainly not surprising that people prefer to have both, but when only one is possible, there is often a strong preference for actions that have a restorative purpose.

In the context of fatal shootings, it might seem that restorative actions are the only ones possible, and even that to a very limited extent, but this assumes that the only harm done is to the deceased. This is unlikely. Though the deceased and his or her family are the most obvious "victims" and are likely dealing with the most pain, incidents like the Williams and Martin shootings typically create ripples of harm that reach far beyond the obvious target. In the case of Williams, it is clear that both the native-American community and the police department felt that they were harmed by the incident.

\footnotetext{
${ }^{9}$ Willingness is sufficient. While a curious mind and an open heart are certainly welcome, they are not required, because while a restorative process does not guarantee any particular result, it does create conditions where it is more likely that participants will eventually begin to see each other's humanity and respond accordingly.
} 
And yet, Restorative Circles are not, at the heart of it, about apologies or even about restorative acts more generally. They are about mutual understanding and connection, which create conditions for the parties in conflict to move forward in mutually more satisfying ways. Restorative processes offer an alternative way to engage racialized conflict (and conflict in general) by allowing those involved to not just understand each other but experience each other's humanity. That is why restorative acts are offered. That is why they are experienced as restorative.

The Restorative Circle in Seattle was held September 13, 2010. It lasted over three hours and was held at the Chief Seattle Club, which Brenneke (2012, When People In Crisis Meet in Sacred Space section) described as "a sacred space designed for traditional Native American healing circles." Brenneke (2012) described the Circle and its outcomes in Tikkun Magazine (Participants' Assessments section):

The Restorative Circle transformed this conflict into an opportunity for healing, increased understanding, critical analysis of policy and practice, and lasting change. The participants courageously walked into the unknown. Eric Williams, John T. Williams's brother, said: "It was painful. I didn't know what I was walking into. It was pretty cool that everyone had a lot to say and share - the police, the lawyers, us."

The participants expressed their difficult, often excruciating, experiences and revealed their hopes and needs for how it could be different. As one police commander stated: "I thought it took immense courage on Rick's part to share so much and was helpful to see other carvers share their hurt/pain. I took away a deeper appreciation of what they do and its challenges. I also took away a share of the sense of loss of a brother, son, friend, and artist."

While tense, sometimes messy, and often uncomfortable, the sharing and mutual respect in the circle allowed for deep conversation between the Seattle Police Department command staff and members of the family that had never happened before. It was safe to be real....

In her article, Brenneke described a variety of ways the Circle increased mutual understanding and built relationships among those present. In many ways, these relationships are more important than any specific agreements made in the Circle, but to the degree that we are interested in systemic change, a process that did not lead to such change would be, at least partially, unsatisfying. In this case, the parties present produced several pages of agreements designed to address the needs of Williams' family, the native community, and the police department (Seattle Times, 2011).

Among the agreements were promised briefings by command staff to patrols at roll calls regarding what transpired during the Circle and a commitment to explore more in-depth changes to Seattle Police Department policies, training, and practices, including a plan to increase understanding and cultural sensitivity to First Nations peoples. The Seattle Police Department also agreed to implement immediate changes to how new officers are trained. Notably, the agreements included a feedback loop back to the Circle participants regarding the implementation of these and other policy changes and personal ongoing communication 
between the police chief and Williams's family regarding the department's investigation into this case.

It appears that the agreements are having the desired effect. According to Brenneke (2012, Participants" Assessments section), Rick Williams reports: "People are seeing a difference in how police are engaging on the streets, it has gotten much better. People tell me that they appreciate what we are doing. What we need are more opportunities for safe, direct, communications like those we had."

Moreover, the Circle also yielded a resolution of the family's civil rights claims (the family and city agreed on a $\$ 1,500,000$ settlement (Seattle 911, 2011), without the unpleasantness and expenses of extended litigation. It also resulted in the police command staff's participation (with support from the family and Native American community) in memorial events honoring John T. Williams and inspired a community healing process - a public art project to carve and raise a totem pole to honor Williams and the native carving tradition.

The Circle also seems to have given Rick Williams the ability to rehumanize the man who shot his brother. According to Brenneke (2012, The Participants Meet Again section), "Rick Williams now articulates the shooting by the officer as a terrible 'mistake arising from fear,' and, along with other participants and community leaders, is exploring the possible adoption of the RC process as part of a long-term strategy for transforming police/community relations in Seattle."

Notably, officer Birk, the man who shot Williams, still had to negotiate the mainstream criminal justice system. In cases of criminal conduct, it is rare that a restorative process like RC would replace a criminal proceeding, though the judge might take what transpired during the restorative process into consideration ${ }^{10}$. In this case, King County Prosecutor Dan Satterberg decided not to bring criminal charges against Birk, which, in the minds of many, demonstrated yet again the failure of the criminal justice system to produce justice.

The Williams case shows a different type of justice system at work, a system that would greatly benefit the Sanford community and serve as a model to the rest of the nation for both how to "do justice" and heal from the tragic events that led to Martin's death ${ }^{11}$. Moreover, unlike our formal justice system, restorative systems can be activated for any conflict, no matter how large or small, which means that a similar (probably much shorter) process to the one just described can also be used to work through racial microaggressions and other types of racial conflicts.

The John T. Williams Circle is unusual in its visibility but not at all atypical in terms of outcomes. To the contrary, the outcomes described by Brenneke (2012) are consistent with a growing body of literature documenting the effectiveness of restorative practices in general and Restorative Circles in particular. As just one example, the United Kingdom-based National Endowment for Science, Technology and the Arts (NESTA), which recently selected Restorative Circles as one of just ten international public programs exemplifying "radical efficiency,"

\footnotetext{
${ }^{10} \mathrm{~A}$ first-degree murder case in which a restorative process took the place of criminal proceedings was recently covered by the New York Times Magazine (Tullis, 2013). In this case, the restorative process, which was supported and attended by both the district attorney and the victim's family, resulted in a 20-year sentence.

${ }^{11}$ Because the Martin case received so much national publicity, it is likely that many individuals outside of Sanford feel impacted by what happened. This raises a variety of interesting and challenging questions regarding who would participate in a restorative process and how such a process could be made transparent to all those who are impacted.
} 
reported a satisfaction rate of $93 \%$ by surveyed participants of 400 Restorative Circles in São Paulo and, in one school district, a $98 \%$ reduction of police school visits following a school-wide adoption of Restorative Circles in 2009 (Gillinson, Horne, \& Baeck, 2010). Moreover, a recent review of research on restorative justice across multiple continents showed that restorative systems reduce recidivism in both violent and property crime in comparison to traditional justice systems and provide a variety of benefits to the "victims", including improved mental health and greater satisfaction with the justice process (Sherman \& Strang, 2007). Especially in the United States, which incarcerates a fifth of the world's prisoners at a cost of more than $\$ 75$ billion a year (Schmitt, Warner, \& Gupta, 2010), these are compelling findings.

Outcome studies are important, but they are unable to capture either the nuances of the process or the internal shifts that typically occur when individuals gather not to blame and punish but to repair and restore. The Williams case provides one such example. Could not the Martin case be another opportunity?

Certainly, in many important ways, the Martin case is different from that of Williams. For one, Zimmerman is not a police officer and, therefore, is not assumed to represent or serve the city and its people. For another, what happened in the moments leading up to the shooting are less clear in Martin's case. The national visibility of the Martin case and the country's different racial history with Black and Native Americans are also significant. No doubt there are other differences. There always are. The point here is not that the two cases are so similar that they should be treated the same way but to show what a restorative response to a situation like Martin's can look like.

I do not know what restorative justice would look like for Martin's family or, for that matter, for Zimmerman. This would be up to them to figure out, along with community members who feel personally impacted by what happened and only after they get to the point of really understanding and humanizing one another. What I do know is that our conventional justice system, even at its best, is severely limited in what it offers, and restorative systems provide the best way I have seen thus far for justice, for healing, and for the kind of world where, at least in matters of justice, there really are not a Black America and a White America. Till's case spurred a social justice movement. It is time now to take the next step.

\section{Contact information:}

Mikhail Lyubansky

Department of Psychology

University of Illinois, Urbana-Champaign, IL, 61820

Email: lyubansk@illinois.edu 


\section{References}

Alcindor, Y. (2012). Poll shows racial divide on views of Trayvon Martin case. Retrieved 5-082012 from http://www.usatoday.com/news/nation/story/2012-04-05/trayvon-martinpoll/54047512/1

Alexander, M. (2010). The New Jim Crow: Mass incarceration in the age of colorblindness. New York: New Press.

Ayres, I. \& Borowsky (2008). A study of racially disparate outcomes in the Los Angeles Police Department. Retrieved from http://www.aclu-sc.org/downloads/2/681086.pdf

Beito, D. \& Beito, L. (2009). Black maverick: T. R. M. Howard's fight for civil rights and economic power. Champaign, IL: University of Illinois Press.

Brenneke, A. (2012). A restorative circle in the wake of a police shooting. Retrieved from http://www.tikkun.org/nextgen/a-restorative-circle-in-the-wake-of-a-police-shooting

Brown, M.K., Carnoy, M., Curie, E., Duster, T., \& Oppenheimer, D.B., Shultx, M., \& Wellman, D. (2003). Whitewashing race: The myth of a color-blind society. Berkeley, CA: University of California Press.

Condon, S. (2012). Obama: "If I had a son, he'd look like Trayvon". Retrieved from http://www.cbsnews.com/8301-503544_162-57403200-503544/obama-if-i-had-a-sonhed-look-like-trayvon/

Eidelson, R. \& Lyubansky, M. (2010). Beliefs in Black and White: How race influences Americans' perceptions of themselves, their racial group, and their national group. In T.S. Philpot and I. K. White (Eds.). African-American political psychology: Identity, opinion, and action in the post-civil rights era. New York: Palgrave MacMillan Press.

Fiske, S. (1989). Examining the role of intent: Toward understanding its role in stereotyping and prejudice. In J. S. Uleman \& J.A. Bargh (Eds.). Unintended thought: The limits of awareness, intention, and control (pp. 253-283). New York: Guilford Press.

Gillinson, S.. Horne, M., \& Baeck, P. (2010). Radical efficiency: Different, better, lower cost public services. NESTA.

Godsil, R., Goff, P., powell, j., Williams, D., \& Hinojosa, M. (2012, April). Plenary session: Unconscious bias and race. Session presented at Kellogg Foundation's America Healing Conference, New Orleans, LA.

Greenwald, A. G., McGhee, D. E., \& Schwartz, J. K. L. (1998). Measuring individual differences in implicit cognition: The Implicit Association Test. Journal of Personality and Social Psychology, 74, 1464-1480.

Huie, W.B. (January 1956). The shocking story of approved killing in Mississippi. Retrieved from http://www.pbs.org/wgbh/amex/till/sfeature/sf_look_confession.html 
Illinois Department of Transportation. (2009). Illinois traffic stop report. Retrieved http://www.dot.il.gov/travelstats/ITSS\%202009\%20Statewide\%20and\%20Agency\%20R eports.pdf

Illinois Department of Transportation (IDOT). (2010). Illinois traffic stop report. Retrieved from http://www.dot.il.gov/travelstats/2010\%20ITSS\%20Statewide\%20and\%20Agency\%20R eports.pdf

Knickerbocker, B. (2012). Poll: Trayvon Martin case divides US by race, age, wealth and politics. Retrieved from http://www.msnbc.msn.com/id/46981884/ns/us_newschristian_science_monitor/

Lundman, R.J. \& Kaufman, R.L. (2003). Driving while black: Effects of race, ethnicity, and gender on citizen self-reports of traffic stops and police actions, Criminology, 41, 195220.

Lyubansky, M. \& Barter, D. (2011). Restorative approaches to racial conflict. Peace Review, 23, 37-44.

Ogletree, C. (2010). The presumption of guilt: The arrest of Henry Louis Gates Jr. and race, class, and crime in America. United Kingdom: Palgrave/Macmillan.

Omi, M. \& Winant, H. (1994). Racial formation in the United States from the 1960 s to the 1990s. New York: Routledge.

Schuman, H., Steeh, C., Bobo, L., \& Krysan, M. (1997). Racial attitudes in America: Trends and interpretations (rev. ed). Cambridge, MA.: Harvard University Press.

Sherman, L.W. \& Strang, H. (2007). Restorative justice: The evidence. London: The Smith Institute.

Seattle 911 (2011). Read the city's settlement with the John T. Williams family. Retrieved from http://blog.seattlepi.com/seattle911/2011/04/29/read-the-citys-settlement-with-thejohn-t-williams-family/

Seattle Times (2011). 9/13/2010 Restorative circle. Retrieved from http://seattletimes.nwsource.com/ABPub/2011/02/02/2014113681.pdf

Schmitt, J., Warner, K., \& Gupta, S. (2010). The high budgetary cost of incarceration. Center for Economic and Policy Research. Washington, D.C.

Tullis, P. (2013). Can forgiveness play a role in criminal justice? Retrieved from http://www.nytimes.com/2013/01/06/magazine/can-forgiveness-play-a-role-in-criminaljustice.html?pagewanted=1\&_r=1\&smid=fb-share

Washington Post. (2004). Transcript: Illinois Senate Candidate Barack Obama. Retrieved from http://www.washingtonpost.com/wp-dyn/articles/A19751-2004Jul27.html 